\begin{tabular}{|c|c|c|c|c|}
\hline JURNAL & VOLUME 1 & NOMOR 1 & HALAMAN 1-70 & $\begin{array}{c}\text { ISSN 2655-8823 }(p) \\
\text { ISSN - }(e)\end{array}$ \\
\hline
\end{tabular}

\title{
KONFLIK AGRARIA \\ DALAM PENGELOLAAN TANAH PERKEBUNAN \\ PADA PT HEVEA INDONESIA (PT HEVINDO) \\ DENGAN MASYARAKAT KECAMATAN NANGGUNG KABUPATEN BOGOR
}

\author{
Meiliani Puji Suharto \\ Mahasiswa Program Studi Kesejahteraan Sosial, FISIP UNPAD \\ E-mail: meiliani97@gmail.com \\ Gigin K. Basar \\ Dosen Program Studi Kesejahteraan Sosial, FISIP UNPAD \\ E-mail: gigin@unpad.ac.id
}

\begin{abstract}
ABSTRAK
Konflik agraria banyak disebabkan oleh adanya kesenjangan sumber daya natural, khususnya kesenjangan dalam penguasaan, persepsi dan konsepsi, serta hukum dan kebijakan yang saling bertentangan. Konflik umumnya terjadi antar individu, antar kelompok, masyarakat maupun pihak-pihak lain, dimana setiap pihak yang berkonflik berupaya untuk dapat menunjukkan kekuatannya agar kepentingannya dapat terwujud dengan baik, salah satunya pada pengelolaan dan penguasaan tanah perkebunan.

Kasus konflik antara PT. Hevea Indonesia (Hevindo) yang berada di Kecamatan Nanggung, Kabupaten Bogor, Jawa Barat dengan masyarakat sekitar terutama masyarakat petani. Konflik karena keterbatasan jumlah lahan milik masyarakat, sementara kebutuhan masyarakat semakin meningkat, baik fungsi maupun manfaat lahan tersebut bagi masyarakat. Akhirnya masyarakat melakukan aksi pendudukan lahan-lahan tersebut di berbagai lokasi HGU. Meskipun sebagian besar cara yang digunakan belum berujung pada tindakan-tindakan radikal.

Artikel ini mengungkapkan teori-teori yang mendukung penyebab terjadinya konflik, melalui penelusuran literatur. Hasil penelitian menungkapkan kronologis konflik yang terjadi dari awal hingga akhir selama satu semester. Pembahasan yang berisi tentang analisis konsep atau teori-teori yang digunakan serta kesimpulan dan saran dari penulis dalam menyikapi isu yang ditulis dan dibahas di dalam artikel ini.
\end{abstract}

Kata kunci: Konflik Agraria, Masyarakat, Perusahaan

ABSTRACT

Agrarian conflicts are mostly caused by gaps or disagreements related to agrarian sources, especially gaps in mastery, perception and conception, as well as conflicting laws and policies. Agrarian conflicts regarding land management and control generally occur between individuals, between groups, communities and other parties, where each party in conflict seeks to show its strength so that its interests can be realized properly, one of which is the management and control of plantation land.

Like conflicts that occur between PT. Hevea Indonesia (Hevindo) located in Nanggung District, Bogor Regency, West Java with surrounding communities, especially the farming community. The conflict between the Nanggung Subdistrict Community and PT Hevindo was caused by the limited number of land owned, while the community's needs increased, both the function and benefits of the land for the community. Finally the community took action to occupy these lands in various HGU locations. Although most of the methods used have not led to radical actions.

In this article also presented theories that support the causes of conflict, research methods that use literature studies, the results of research that discusses the chronological conflict that occurred from the beginning to the end of the sixth semester, a discussion that contains analysis of concepts or theories used and conclusions and suggestions from the author in addressing the issues written and discussed in this article.

Keywords: Agrarian Conflict, Society, Company

\section{PENDAHULUAN}

Sejak zaman Orde Baru konflik sudah sering terjadi, salah satunya adalah konflik agraria. Konflik agraria ternyata banyak disebabkan akibat adanya kesenjangan atau ketidakserasian terkait sumber-sumber agraria, khususnya kesenjangan dalam penguasaan, persepsi dan konsepsi, serta 


\begin{tabular}{|c|c|c|c|c|}
\hline $\begin{array}{c}\text { JURNAL } \\
\text { KOLABORASI RESOLUSI KONFLIK }\end{array}$ & VOLUME 1 & NOMOR 1 & HALAMAN 1-70 & $\begin{array}{c}\text { ISSN 2655-8823 }(p) \\
\text { ISSN - }(e)\end{array}$ \\
\hline
\end{tabular}

hukum dan juga kebijakan yang saling bertentangan. Dalam konflik agraria biasanya lebih berfokus pada penguasaan dan pengelolaan agraria yang mencakup tanah, air dan udara. Pengelolaan dan penguasaan agraria dikelola oleh negara untuk kepentingan masyarakat paling banyak terjadi dan sering menjadi pembahasan adalah mengenai pengelolaan tanah. Tujuan dari pengelolaan tanah oleh pemerintah pada dasarnya diperuntukan untuk kesejahteraan masyarakat sesuai dengan amanat undang-undang. Namun, pada kenyataannya pengelolaan tersebut masih jauh dari apa yang diamanatkan dalam undang-undang sehingga memunculkan konflik.

Konflik agraria mengenai pengelolaan dan penguasaan tanah umumnya terjadi antar individu, antar kelompok, masyarakat maupun pihak-pihak lain, dimana setiap pihak yang berkonflik berupaya untuk dapat menunjukkan kekuatannya agar kepentingannya dapat terwujud dengan baik, salah satunya pada pengelolaan dan penguasaan tanah perkebunan. Biasanya keberpihakan dilakukan oleh pemerintah yang lebih condong kepada sekelompok orang seperti para pemodal besar, para pengusaha baik pengusaha lokal maupun pengusaha asing yang dipercaya dapat melakukan pengelolaan dan penguasaan atas tanah perkebunan. Perusahaanperusahaan yang mengelola perkebunan tersebut tentu membawa dampak positif, tetapi tak sedikit pula dampak negatif yang diberikan kepada masyarakat tanpa memperhatikan tata kelola lingkungan yang baik dan juga kondisi masyarakat yang berada di kawasan perkebunan maupun disekitar perusahaan.

Berdasarkan data yang diperoleh dari Badan Pertanahan Nasional (BPN) pada tahun 2002 telah tercatat bahwa perkebunan besar yang merupakan perkebunan milik negara dan swasta memliki luas 3,55 juta hektar dengan rata-rata luas kebun dengan Hak Guna Usaha (HGU) sekitar 530 hektar pada perusahaan swasta. Berbeda dengan luas kebun dengan HGU pada negara yang memiliki luas rata-rata sekitar 2.800 hektar (Hidayati, 2003). Kemudian Departemen Pertanian mencatat bahwa rata-rata luas kepemilikan rakyat atas perkebunan swadaya pada tahun 2002 sekitar 0,7 hektar.

Pada tahun 1993, di Pulau Jawa luas penguasaan lahan per keluarga hanya sekitar 0,41 hektar. Dengan ini diperkirakan rata-rata luas lahan milik keluarga semakin menyusut. Demikian dengan para petani yang hanya menjadi penggarap tanpa tanah atau lahan perkebunan yang jumlahnya sudah tak terhitung lagi. Semakin hari tekanan ekonomi akibat ketidakadilan penguasaan lahan melukai harga diri dan merampas eksistensi sosial petani, dan menjadi pendorong kuat pembentukan gerakan masyarakat petani. Gerakan masyarakat petani dilakukan untuk memulihkan kembali eksistensi mereka dengan melakukan sejumlah perlawanan. Perlawanan tersebut dilakukan oleh masyarakat petani dijadikan sebagai upaya untuk mempertahankan hak-haknya agar diwujudkan dalam berbagai bentuk, mulai dari protes bisu hingga dalam bentuk kekerasan.

Menurut Direktorat Jendral Perkebunan dalam Kompas (2003) menyebutkan bahwa penyebab dan pemicu terjadinya konflik perkebunan sampai Agustus 2003, lebih berkaitan dengan kepemilikan tanah, baik di sektor swasta yang berjumlah sekitar 225 kasus, maupun negeri seperti PTPN sekitar 350 kasus. Di sektor swasta, secara berturut-turut di sebabkan oleh garapan dan okupasi sekitar 39 kasus, ganti rugi dan tuntutan masyarakat untuk pengembalian tanah sekitar 30 kasus, tanah masyarakat yang diambil perusahaan sekitar 18 kasus, tanah adat/ulayat sekitar 15 kasus, dan tumpang tindih alokasi lahan untuk perusahaan perkebunan sekitar 5 kasus yang terjadi antara masyarakat yang berkeberatan atas perpanjangan atau pemberian izin HGU.

Di Jawa Barat sendiri, konflik agraria sangat rentan untuk terjadi yang disebabkan karena pertentangan kepentingan. Biasanya 


\begin{tabular}{|c|c|c|c|c|}
\hline $\begin{array}{c}\text { JURNAL } \\
\text { KOLABORASI RESOLUSI KONFLIK }\end{array}$ & VOLUME 1 & NOMOR 1 & HALAMAN 1-70 & $\begin{array}{c}\text { ISSN 2655-8823 }(p) \\
\text { ISSN - }(e)\end{array}$ \\
\hline
\end{tabular}

konflik tersebut terjadi antara perusahaan pemegang Hak Guna Usaha (HGU) yang dikeluarkan oleh pemerintah. Salah satunya seperti konflik yang terjadi antara PT. Hevea Indonesia (Hevindo) yang berada di Kecamatan Nanggung, Kabupaten Bogor, Jawa Barat dengan masyarakat sekitar terutama masyarakat petani.

Konflik yang terjadi antara Masyarakat Kecamatan Nanggung dengan PT Hevindo disebabkan karena keterbatasan jumlah lahan milik, sementara kebutuhan masyarakat semakin meningkat, baik fungsi maupun manfaat lahan tersebut bagi masyarakat. Lahan seluas 310,783 ha yang digarap oleh PT Hevindo di Kecamatan Nanggung yang statusnya masih dalam kajian Badan Pertanahan Nasional (BPN) Kabupaten Bogor akibat bersengketa dengan warga. Masyarakat Kecamatan Nanggung yang meliputi tiga desa yaitu Desa Curugbitung, Desa Nanggung, dan Desa Cisarua berusaha untuk memperjuangkan hak-haknya dengan merebut atau mengambil alih tanah-tanah kosong milik HGU yang 75\% tidak dipakai secara produktif sudah hampir puluhan tahun ini. Akhirnya masyarakat melakukan aksi pendudukan lahan-lahan tersebut di berbagai lokasi HGU. Meskipun sebagian besar cara yang digunakan belum berujung pada tindakan-tindakan radikal.

Melihat dari isu konflik tersebut, maka penulis pun tertarik untuk mengangkat isu tersebut untuk dibahas dalam artikel ini yakni tentang konflik agraria terkait penggunaan lahan atau tanah antara PT. Hevindo dengan masyarakat khususnya petani di Kecamatan Nanggung Kabupaten Bogor.

\section{TINJAUAN PUSTAKA Pengertian Konflik}

Konflik adalah perjuangan yang dilakukan oleh berbagai pihak untuk memperoleh hal-hal yang langka seperti nilai, status, kekuasaan, otoritas, dan lain sebagainya, dimana tujuan dari mereka bertikai itu tidak hanya untuk memperoleh keuntungan, tetapi juga untuk menundukkan saingannya dengan kekerasan atau ancaman (Ibrahim, 2002). Sedangkan menurut Mitchell, et al. (2000) dan Hendricks (2004), konflik merupakan sesuatu yang tak terelakkan, yang dapat bersifat positif dan negatif. Aspek positif muncul ketika konflik membantu mengidentifikasi proses pengelolaan sumberdaya dan lingkungan yang tidak berjalan secara efektif, mempertajam gagasan atau informasi yang tidak jelas, dan menjelaskan kesalapahaman.

Konflik menjadi salah satu proses sosial yang bersifat disosiatif, selain persaingan (competition) dan pertentangan. Sebenarnya proses sosial disosiatif tidaklah selalu bersifat negatif, ada kalanya jika diatur sedemikian rupa dapat menghasilkan hal-hal yang positif. Konflik juga bermanfaat, yaitu ketika mempertanyakan status quo.

Menurut Fisher (2001: 4) konflik dapat dikatakan sebagai suatu oposisi atau pertentangan pendapat antara orang-orang, kelompok-kelompok atau organisasiorganisasi yang disebabkan oleh adanya berbagai macam perkembangan dan perubahan dalam bidang manajemen serta menimbulkan perbedaan pendapat, keyakinan dan ide. Konflik terjadi ketika tujuan masyarakat tidak sejalan dan muncul karena ketidakseimbangan antara hubungan-hubungan itu. Misalnya seperti kesenjangan status sosial, kurang meratanya kemakmuran dan akses yang tidak seimbang terhadap sumber daya, serta kekuasaan yang tidak seimbang, kemudian menimbulkan masalah-masalah seperti diskriminasi, pengangguran, kemiskinan, penindasan dan kejahatan. Maka wajar jika seandainya dalam waktu yang cukup lama terjadi perbedaan-perbedaan pendapat diantara mereka.

\section{Tipe Konflik}

Pada dasarnya konflik memiliki beberapa tipe menurut Fisher (2001: 6) diantaranya adalah sebagai berikut:

1. Tanpa Konflik. Pada tipe ini setiap kelompok atau masyarakat yang 


\begin{tabular}{|c|c|c|c|c|}
\hline $\begin{array}{c}\text { JURNAL } \\
\text { KOLABORASI RESOLUSI KONFLIK }\end{array}$ & VOLUME 1 & NOMOR 1 & HALAMAN 1-70 & $\begin{array}{c}\text { ISSN 2655-8823 }(p) \\
\text { ISSN - }(e)\end{array}$ \\
\hline
\end{tabular}

hidup damai, jika mereka ingin agar keadaan ini terus berlangsung, mereka harus hidup bersemangat dan dinamis, memanfaatkan konflik perilaku dan tujuan, serta mengelola konflik secara kreatif.

2. Konflik Laten. Tipe konflik ini bersifat tersembunyi dan perlu diangkat ke permukaan sehingga dapat ditangani secara efektif.

3. Konflik Terbuka adalah yang berakar dalam dan sangat nyata dan memerlukan berbagai tindakan untuk mengatasi akar penyebab dan berbagai efeknya

4. Konflik Permukaan memiliki akar yang dangkal atau tidak berakar dan muncul karena kesalahpahaman mengenai sasaran yang dapat diarasi dengan meningkatkan komunikasi.

\section{Teori-teori Mengenai Berbagai Penyebab Konflik}

Dalam membantu memahami cara-cara mengelola konflik, terdapat beberapa teori yang dapat digunakan untuk mengetahui penyebab konflik dengan pendekatan metode dan sasaran yang berbeda. Adapun teori-teori untuk mengetahui berbagai penyebab konflik menurut Fisher (2001: 89) diantaranya sebagai berikut:

1. Teori Hubungan Masyarakat. Didalam teori ini menganggap bahwa konflik disebabkan oleh polarisasi yang terus terjadi, ketidakpercayaan dan permusuhan diantara kelompok yang berbeda dalam suatu masyarakat.

2. Teori Negosiasi Prinsip. Dalam teori ini menganggap bahwa konflik disebabkan oleh posisi-posisi yang tidak selaras dan perbedaan pandangan tentang konflik oleh pihak-pihak yang mengalami konflik.

3. Teori Kebutuhan Manusia. Teori ini berasumsi bahwa konflik berakar dalam yang disebabkan oleh kebutuhan dasar manusia seperti fisik, mental, dna sosial yang tidak dapat terpenuhi atau terhalangi.

4. Teori Identitas. Teori ini beasumsi bahwa konflik disebabkan karena identitas yang terancam, yang sering berakar pada hilangnya sesuatu atau penderitaan di masa lalu yang tidak diselesaikan.

5. Teori Kesalahpahaman

Antarbudaya. Dalam teori ini berasumsi bahwa konflik disebabkan oleh ketidakcocokan dalam cara-cara komunikasi diantara berbagai budaya yang berbeda.

6. Teori Transformasi Konflik. Dalam teori ini berasumsi bahwa konflik disebabkan oleh masalah-masalah ketidaksetaraan dan ketidakadilan yang muncul sebagai masalahmasalah sosial, budaya dan ekonomi.

\section{METODE PENELITIAN}

Penelitian ini menggunakan studi literatur, dimana data yang diambil adalah sebagai data sekunder. Metode studi literatur ini merupakan serangkaian kegiatan yang berkenaan dengan metode pengumpulan data pustaka seperti dengan membaca dan mencatat, serta mengelola bahan penelitian. Metode ini dilakukan dengan tujuan untuk mengungkapkan berbagai teori-teori yang relevan dengan permasalahan yang sedang dihadapi atau sedang diteliti sebagai bahan rujukan dalam hasil dan pembahasan.

Dalam melakukan penelitian ini, hal-hal yang harus dilakukan yaitu dengan melakukan teknik penyusunan yang sistematis untuk memudahkan langkahlangkah yang akan diambil. Adapun langkah yang harus dilakukan oleh peneliti yaitu dengan melakukan studi literatur pada jurnal, buku-buku, berita dan penelitian yang telah dilakukan berkaitan dengan konflik agraria mengenai pengelolaan tanah atau lahan antara masyarakat petani di Kecamatan Nanggung dengan PT Hevea Indonesia (Hevindo). Selanjutnya adalah 


\begin{tabular}{|c|c|c|c|c|}
\hline $\begin{array}{c}\text { JURNAL } \\
\text { KOLABORASI RESOLUSI KONFLIK }\end{array}$ & VOLUME 1 & NOMOR 1 & HALAMAN 1-70 & $\begin{array}{c}\text { ISSN 2655-8823 }(p) \\
\text { ISSN - }(e)\end{array}$ \\
\hline
\end{tabular}

menentukan lokasi penelitian dan sasaran penelitian. Dalam hal ini lokasi konflik yang dituju adalah di Kecamatan Nanggung yang meliputi tiga desa yaitu Desa Curugbitung, Desa Nanggung dan Desa Cisarua yang berada di Kabupaten Bogor, Jawa Barat. Sasaran atau pelaku konflik yang akan diteliti adalah pihak dari PT Hevindo dan masyarakat Kecamatan Nanggung, Kabupaten Bogor.

\section{HASIL DAN PEMBAHASAN Hasil Penelitian}

PT Hevea Indonesia (Hevindo) merupakan perusahaan perkebunan swasta yang bergerak dalam bidang perkebunan karet beserta pengelolaan hasilnya yang didirikan pada tanggal 11 Juli 1981. Sebelumnya perusahaan ini bernama PT Cengkeh Zansibar yang pembentukannya tercantum dalam Berita Negara RI No. 90 tanggal 8 November 1974. Perushaan ini menjalankan usahanya dengan satu tujuan utama yaitu khusus mengusahakan di bidang perkebunan cengkeh sebagai realisasi cita-cita pemerintah dan Gabungan Perserikatan Pabrik Rokok Indonesia untuk berswasembada cengkeh.

Konflik yang terjadi antara masyarakat Kecamatan Nanggung dengan PT Hevindo disebabkan karena keterbatasan jumlah lahan milik, sementara kebutuhan masyarakat semakin meningkat, baik fungsi maupun manfaat lahan tersebut bagi masyarakat. Sejak tahun 1993, lahan HGU PT Hevea Indonesia (Hevindo) ini tidak digarap sebagaimana mestinya sesuai peruntukannya. Hingga tahun 1997 hampir sekitar 75\% lahan HGU tersebut tidak digarap secara produktif oleh PT Hevindo. Bahkan di dalam areal HGU tersebut beroperasi kegiatan pertambangan galian-c, beberapa peternakan ayam, serta rumahrumah tinggal di daerah tersebut. Dengan kenyataan penelantaran lahan tersebut, maka sejak tahun 1997 secara bertahap sekitar $700 \mathrm{kk}$ warga tiga desa tersebut mulai menggarap dan mengelola lahan tersebut secara produktif dengan cara menanami tanaman pangan, buah-buahan dan tanaman besar yang menghasilkan kayu.

Konflik yang terjadi merupakan bentuk perlawanan dari masyarakat, baik yang bermotif ekonomi maupun non-ekonomi. Perlawanan dengan motif ekonomi tampak pada pemenuhan kebutuhan ekonomi masyarakat, seperti menanam singkong, talas, pisang dan sayuran meski tidak diijinkan pihak perusahaan. Perlawanan juga bersumber dari kebutuhan akan ruang kelola (kebutuhan atas lahan pertanian) oleh masyarakat, hal ini disebabkan karena tingkat kepemilikan lahan masyarakat di desa pada umumnya kecil. Sedangkan perlawanan yang bermotif non-ekonomi bersumber dari upaya masyarakat untuk mengungkap ketidakadilan sosial yang telah dilakukan perusahaan terhadap masyarakat yang puluhan tahun hidup di wilayah enclave (wilayah kantung).

Kronologis konflik ini berawal dari luas lahan HGU yang semakin berkurang yang awalnya ada sekitar 1200 hektar menjadi 500 hektar setelah adanya program sertifikasi tanah oleh pemerintah untuk memberikan kesempatan kepada masyarakat yang tidak memiliki tanah dan bertahun-tahun telah menggarap tanah tersebut pada tahun 1983. Namun masyarakat tidak semuanya mengerti mengenai program sertifikasi tanah tersebut sehingga beberapa oknum memanfaatkan situasi tersebut dengan melibatkan beberapa tokoh masyarakat seperti kepala desa dan camat. Luasan tanah berkurang karena setiap desa diminta sekitar 20 hektar dengan alasan untuk tanah pemerintah daerah yang akan digunakan untuk pembangunan infrastruktur desa, namun tidak sepenuhnya berhasil.

Pada masa peralihan yang memakan waktu sekitar 3 tahun, peristiwa-peristiwa yang memicu konflik dimulai, meskipun tidak mencuat. Para tokoh masyarakat di tiga desa (Nanggung, Curugbitung dan Cisarua) saat itu meminta kepada PT Hevindo untuk memberikan 20 hektar lahan yang akan digunakan dalam rangka pemberdayaan ekonomi masyarakat dan 


\begin{tabular}{|c|c|c|c|c|}
\hline $\begin{array}{c}\text { JURNAL } \\
\text { KOLABORASI RESOLUSI KONFLIK }\end{array}$ & VOLUME 1 & NOMOR 1 & HALAMAN 1-70 & $\begin{array}{c}\text { ISSN 2655-8823 }(p) \\
\text { ISSN - }(e)\end{array}$ \\
\hline
\end{tabular}

pembangunan infrastruktur desa. Hal ini dilakukan karena dirasakan selama ini perusahaan jarang memberikan bantuan kepada masyarakat. Beberapa tahun kemudian, masyarakat meminta perusahaan agar mengijinkan mereka melakukan kegiatan pertanian di lahan-lahan kososng, namun tidak diizinkan.

Pada tahun 1995, beberapa pemuda dan masyarakat mulai membuka lahan kosong milik HGU tanpa sepengetahuan direksi, yang sebelumnya telah diketahui bahwa tanah tersebut mengandung unsur galian teras (galian C) yang dapat digunakan untuk bahan bagunan pembuatan batu bata. Kegiatan ini telah diijinkan oleh pihak mandor kebun tanpa sepengetahuan pimpinan direksi. Dalam kurun waktu 6 bulan dilakukan penggalian di wilayah tersebut, kemudian penggalian dihentikan karena dilarang oleh pihak perkebunan. Setelah beberapa waktu dilakukan pelarangan dari pihak direksi dan diancam akan dilaporkan pada polisi. Pasca pelarangan, pihak mandor bersepakat untuk meneruskan dan menyetujui adanya pajak konvensional dari penggali yang diberikan kepada mandor perkebunan saat itu.

Dalam hal ini aparat kepolisian turut terlibat. Keterlibatan aparat kepolisian dalam kasus tanah galian teras membuat masing-masing pihak terkesan menutunutupi konflik yang sedang terjadi, yaitu konflik antara pemegang HGU PT Hevindo dan masyarakat desa, serta keterlibatan pihak lain dalam konflik tersebut. Beberapa pekerja menyebutkan bahwa setiap bulan ada polisi yang datang untuk menerima setoran "uang keamanan" dari para pengusaha.

Pada tahun 1997, saat krisis moneter beberapa masyarakat melakukan pembukaan lahan milik HGU yang telah banyak ditumbuhi alang-alang. Kegiatan ini berlangsung sampai tahun 1980-an, namun masih dalam luasan kecil. Hal ini dilakukan dengan alasan kebutuhan ekonomi yang mendesak, sedangkan lahan yang ada tidak mampu memenuhi kecukupan mereka dan lahan hanya dikuasai oleh beberapa orang saja. Setelah selesai digarap menjadi kebun dan ditanami, pihak perusahaan mendesak masyarakat penggarap untuk meninggalkan lahan tersebut, mencabuti tanaman mereka secara paksa, bahkan sampai melibatkan aparat keamanan.

Beberapa minggu kemudian mandor perkebunan mengedarkan surat perjanjian bagi masyarakat penggarap lahan HGU. Pembagian hasil ini hanya kesepakatan dengan mandor tanpa dicantumkan dalam surat perjanjian, sebesar 50:50 dari hasil panen, untuk penggarap dan mandor. Disebutkan dalam surat tersebut bahwa perusahaan sewaktu-waktu akan mengambil lahan tersebut, tanpa ganti rugi dalam bentuk apapun. Kebanyakan masyarakat waktu itu tidak membaca dan memahami isi surat tersebut, sehingga dengan mudah perusahaan mendapatkan tanda tangan tanpa perlawanan. Surat tersebut dikenal dengan "surat pemutihan".

Pada tahun 1999, mandor perkebunan mengeluarkan surat untuk kedua kalinya, namun perihal surat kali ini tentang tumpang sari. Setiap penggarap dikenai biaya sebesar RP. 2.500. Bagi penggarap yang tidak membayar, mereka diancam akan diusir dari lahan garapannya. Kegiatan ini berlangsung hingga tahun 2000, karena terjadi pergantian manajer kebun. Pihak direksi menganggap bahwa manajer kebun sebelumnya kurang bisa menjalankan perusahaan dengan benar maka digantilah dengan yang baru. Dalam pergantian manajer ini meskipun sudah terdapat pelarangan tidak boleh membuka lahan HGU perusahaan, akan tetapi masyarakat masih tetap meneruskan kegiatannya untuk menggarap lahan yang tidak ada tanaman karetnya. Hal tersebut tidak diketahui oleh PT Hevindo. Kegiatan ini berlangsung hingga 15 September 2003 sampai akhirnya terjadi pengusiran terhadap salah satu warga yang mendirikan pondok di lahan HGU perusahaan.

Kemudian pada bulan Februari 2004 mandor juga melakukan pencabutan sepihak terhadap semua tanaman salah satu penggarap. Kejadian tersebut sudah 


\begin{tabular}{|c|c|c|c|c|}
\hline $\begin{array}{c}\text { JURNAL } \\
\text { KOLABORASI RESOLUSI KONFLIK }\end{array}$ & VOLUME 1 & NOMOR 1 & HALAMAN 1-70 & $\begin{array}{c}\text { ISSN 2655-8823 }(p) \\
\text { ISSN - }(e)\end{array}$ \\
\hline
\end{tabular}

dianggap bukan sesuatu yang biasa, meski mereka sadar bahwa tanah yang digarap adalah tanah HGU. Perlakuan pihak PT Hevindo yang apatis membuat masyarakat bersepakat untuk memberikan perlawanan. Maka dari itu masyarakat bersepakat untuk membentuk suatu perkumpulan (aliansi) yang bernama AMANAT (Aliansi Masyarakat Nanggung Transformatif) yang dijadikan sebagai wadah perjuangan para petani penggarap di tiga desa yaitu Desa Nanggung, Desa Curugbitung dan Desa Cisarua. Dalam perjalanannya, aliansi ini pun membangun jaringan dengan beberapa LSM yang peduli terhadap perjuangan para petani penggarap di tiga desa, LSM tersebut antara lain RMI (dalam hal ini RMI ditempatkan sebagai CO), KPA, HUMA, JKPP, SAWIT WACH dan jaringanjaringan lain. AMANAT sebagai bentuk perjuangan kaum tani yang ada di tiga desa di Kecamatan Nanggung.

Intimidasi yang dialami masyarakat kembali terjadi pada bulan Desember 2010, dimana BPN Kanwil Jabar melakukan aktivitas pengukuran dan pemasangan patok untuk menandai batas-batas areal HGU. Selanjutnya Bupati Bogor melalui surat tanggal 23 Juni 2011 yang ditujukan kepada kepala BPN RI memberikan pertimbangan teknis untuk persyaratan perpanjangan masa berlaku HGU PT Hevea Indonesia, yang pada intinya Bupati Bogor memberikan persetujuannya untuk perpanjangan HGU PT Hevea Indonesia. Masyarakat menolak pemberian perpanjangan $\mathrm{HGU}$, dengan pertimbangan kenyataan fisik perkebunan yang telah tidak digarap secara produktif oleh PT Hevea Indonesia dan perusahaan tidak memberikan manfaat/ impact positif bahkan melakukan perusakan tanaman masyarakat di tanah garapan. Perusakan tanaman dan kehadiran para preman dalam proses perusakan tanaman warga ini telah menimbulkan kecemasan, ketakutan dan rasa tidak aman dari warga masyarakat.

Pada tanggal 22 April 2013, AMANAT bersama para petani melakukan aksi unjuk rasa di depan gedung DPRD dan
Pemerintah Kabupaten Bogor. AMANAT pun melaporkan tindakan-tindakan dari PT Hevindo kepada Komisi Nasional Hak Azasi Manusia (KOMNASHAM) karena selama ini telah melakukan tindakantindakan yang tidak baik pada masyarakat di Kecamatan Nanggung, Kabupaten Bogor. Pergerakan perjuangan hak atas tanah harus dilakukan secara masif dan komprehensif. Artinya gerakan ini harus menyentuh seluruh level yang berhubungan dan berkesinambungan.

\section{Pembahasan}

Konflik yang terjadi cenderung termasuk ke dalam tipe konflik tertutup (laten) yang terjadi dalam jangka waktu yang cukup lama. Hal itu dibuktikan ketika aparat kepolisian yang turut terlibat dalam kasus tanah galian teras membuat masingmasing pihak terkesan menutup-nutupi konflik yang sedang terjadi, yaitu konflik antara pemegang HGU PT Hevindo dan masyarakat Kecamatan Nanggung, serta keterlibatan pihak lain dalam konflik tersebut. Alasannya karena perusahan belum bisa untuk menangani hal ini karena ditakutkan akan memperkeruh konflik yang terjadi di Kecamatan Nanggung, seperti pemobilisasian massa oleh tokoh masyarakat yang berujung pada aksi rekliming terhadap lahan HGU. Tentu saja hal tersebut terjadi karena kecakapan para elit lokal (tokoh masyarakat) untuk meredam terjadi konflik hingga tidak dapat terbaca oleh pihak-pihak di luar wilayah tersebut, meskipun pernah mencuat dan terbuka.

Selain itu konflik laten yang dicirikan dari kasus konflik antara PT Hevindo dengan Masyarakat Kecamatan Nanggung yakni dengan adanya tekanan-tekanan yang tidak tampak, tidak sepenuhnya berkembang, dan belum terangkat ke puncak konflik, serta seringkali salah satu atau kedua pihak belum menyadari adanya konflik bahkan paling potensi sekalipun. Negosiasi yang kuat dan dukungan pihak keamanan menjadikan masing-masing pihak yang bersengketa dapat mengambil 


\begin{tabular}{|c|c|c|c|c|}
\hline $\begin{array}{c}\text { JURNAL } \\
\text { KOLABORASI RESOLUSI KONFLIK }\end{array}$ & VOLUME 1 & NOMOR 1 & HALAMAN 1-70 & $\begin{array}{c}\text { ISSN 2655-8823 }(p) \\
\text { ISSN - }(e)\end{array}$ \\
\hline
\end{tabular}

jalan keluar atau berdiam diri, meski salah satu atau keduanya sama-sama mengalami kerugian. Setelah beberapa sesepuh desa meninggal, maka mulai banyak muncul masalah dalam desa.

Namun pada tahun 2004, kasus konflik ini mulai muncul ke pihak luar dan berubah menjadi konflik di permukaan dimana tipe konflik ini muncul hanya karena kesalahpahaman antara pihak PT Hevindo dengan Masyarakat Kecamatan Nanggung. Konflik ini diketahui oleh RMI yaitu sebagai salah satu LSM yang melakukan intervensi terhadap masyarakat dah HuMa. Masyarakat datang ke RMI dan mendiskusikan masalah-masalah yang ada, kemudian hasilnya mereka musyawarahkan dengan masyarakat dan anggota KPC yang lainnya. Selanjutnya RMI hanya mengawasi implementasi dan perkembangan dari kesepakatan yang telah dipilih oleh masyarakat. Pendampingan yang intensif dan akses yang dimiliki RMI kepada pihak lain telah banyak merubah sikap dan perilaku masyarakat dalam menghadapi konflik yang terjadi dengan Hevindo. Sedangkan HuMa membantu dalam konsultasi tentang tindakan yang akan dilakukan masyarakat berkaitan dengan bidang hukum. Akan tetapi konflik ini tidak sampai menjadi konflik terbuka yang diketahui oleh banyak pihak luar.

\section{Teori yang Digunakan}

Melihat dari peristiwa konflik yang terjadi antara PT Hevindo dengan Masyarakat Kecamatan Nanggung, maka teori yang sesuai untuk mengkaji fenomena tersebut dapat digunakan dengan 2 teori mengenai penyebab konflik, yaitu teori hubungan masyarakat dan teori transformasi konflik. Alasan digunakan kedua teori tersebut yakni: (1) konflik muncul karena komunikasi yang tidak dapat berjalan sebagaimana mestinya sehingga muncul ketidakpercayaan, perbedaan persepsi dan permusuhan antara perusahaan dengan masyarakat; dan (2) konflik terjadi karena disebabkan oleh masalah-masalah yang memunculkan ketidaksetaraan serta ketidakadilan dimana kedua hal tersebut muncul sebagai masalah sosial dan ekonomi. Kemudian diluar itu, alasan lainnya adalah supaya konflik dapat diselesaikan secara efektif nantinya.

Teori hubungan masyarakat digunakan dengan tujuan untuk meningkatkan komunikasi dan saling pengertian antara perusahaan dengan masyarakat. Sejauh ini yang dilihat bahwa konflik terjadi karena perbedaan pemahaman yang disebabkan oleh kurangnya komunikasi antara pihak perusahaan dan masyarakat serta lembaga lain yang ikut terlibat dalam konflik ini. Informasi yang diterima oleh masingmasing pihak dapat menyebabkan perbedaan persepsi, sehingga terjadi perbedaan dalam menterjemahkan sesuatu. Maka sangat teori ini dirasa sesuai untuk menangani konflik yang terjadi antara PT Hevindo dengan Masyarakat Kecamatan Nanggung.

Teori yang kedua adalah teori transformasi konflik. Teori ini digunakan karena ingin mengubah struktur dan kerangka kerja yang menyebabkan ketidaksetaraan dan ketidakadilan, termasuk kesenjangan ekonomi yang terjadi pada masyarakat dimana tidak diberikan izin untuk membuka lahan pertanian seperti menanam singkong, talas, pisang dan sayuran. Masyarakat pun merasa bahwa kepedulian perusahaan terhadap masyarakat sangat tidak banyak. Selain itu teori ini digunakan untuk meningkatkan jalinan hubungan dan sikap jangka panjang antara PT Hevindo, masyarakat serta pihak-pihak luar yang terkait yang tentunya untuk meningkatkan kesejahteraan sosial masyarakat. Diharapkan dari sini muncul programprogram pemberdayaan dari perusahaan kepada masyarakat supaya keadilan dan perdamaian kembali terjadi diantara kedua tokoh utama dari konflik tersebut, yakni PT Hevindo dan Masyarakat Kecamatan Nanggung. 


\begin{tabular}{|c|c|c|c|c|}
\hline $\begin{array}{c}\text { JURNAL } \\
\text { KOLABORASI RESOLUSI KONFLIK }\end{array}$ & VOLUME 1 & NOMOR 1 & HALAMAN 1-70 & $\begin{array}{c}\text { ISSN 2655-8823 }(p) \\
\text { ISSN - }(e)\end{array}$ \\
\hline
\end{tabular}

\section{KESIMPULAN DAN SARAN Kesimpulan}

Penyebab konflik agraria yang terjadi di Kecamatan Nanggung yang disebabkan oleh perbedaan kepentingan, pemahaman, peningkatan jumlah penduduk, pembatasan akses masyarakat lokal terhadap sumberdaya, keterpurukan ekonomi, juga karena perubahan iklim politik setelah reformasi dan krisis moneter. Kekuatan masing-masing pihak dan dukungan dari pihak lain, menjadikan konflik yang terjadi cukup bertahan lama yakni sejak tahun 1993 sampai akhir tahun 2013.

Anggapan masyarakat yang timbul saat itu bahwa mereka bebas mengajukan keinginan kepada pemerintah dan bebas menyuarakan aspirasi mereka. Kebutuhan akan lahan pertanian menjadi salah satu penyebab munculnya konflik di desa ini, selain perbedaan pemahaman, perbedaan kepentingan, dan kehadiran pihak ketiga, seperti LSM menjadi pemicu mencuatnya konflik, karena masyarakat mulai disadarkan pada apa pentingnya tanah bagi kehidupan di masa yang akan datang. Selain itu berbagai bentuk perlawanan juga dilakukan.

Karakteristik konflik pengelolaan sumberdaya alam yang terjadi di Kecamatan Nanggung berdasarkan tipe konflik termasuk ke dalam konflik yang cenderung tertutup (laten) dalam jangka waktu yang cukup lama. Hal tersebut terjadi karena kecakapan para elit lokal (tokoh masyarakat) untuk meredam terjadi konflik hingga tidak dapat terbaca oleh pihak-pihak di luar wilayah tersebut, meskipun pernah mencuat dan terbuka.

Resolusi konflik yang dilakukan adalah dengan membentuk aliansi bernama AMANAT (Aliansi Masyarakat Nanggung Transformatif) yang dijadikan sebagai wadah perjuangan para petani penggarap Kecamatan Nanggung. Kemudian dilakukan pula mediasi melalui LSM dan juga KOMNASHAM.

\section{Saran}

Adapun saran yang dapat diberikan melihat dari isu konflik agraria tentang pengelolaan tanah atau lahan antara PT Hevea Indonesia (PT Hevindo) dengan Masyarakat Kecamatan Nanggung, Kabupaten Bogor adalah sebagai berikut:

1. Pihak-pihak yang berkonflik dan yang terlibat dalam konflik bersama-sama untuk memperbaiki hubungan koordinasi, dan melakukan pertemuan secara resmi agar dapat dilakukan upaya penyelesaian konflik sampai pada akarnya. Kegiatan ini bisa menggunakan pihak pemerintah daerah sebagai pihak ketiga yang netral dan dipercaya oleh kedua belah pihak (arbitrasi). Selain itu, hal ini juga dapat mengurangi adanya konflik laten yang terjadi diantara masing-masing pihak.

2. Upaya-upaya penyelesaian konflik, sebaiknya tidak menggunakan pendekatan paksaan dan keamanan (coercive), karena akan selalu berbenturan dengan hak-hak yang dimiliki oleh setiap masyarakat, sehingga sumber utama konflik menjadi tidak tersentuh.

3. Pendekatan penyelesaian konflik sebaiknya dilakukan dengan lebih persuasif melalui pendekatan kesejahteraan, seperti pemberian modal usaha, pengkoordiniran para penggarap dan membaginya ke dalam kelompok-kelompok wilayah tertentu, serta membuat perjanjian dengan semua penggarap melalui kelompok tersebut untuk menggarap di wilayah-wilayah tertentu saja, menjadi salah satu alternatif penyelesaian konflik.

4. Setiap bentuk-bentuk upaya penyelesaian konflik sebaiknya dilakukan secara bersama-sama dengan melibatkan masyarakat, penggarap, tokoh pemuda, koramil, pemerintahan kecamatan, polsek, tokoh desa, LSM yang terlibat, serta 


\begin{tabular}{|c|c|c|c|c|}
\hline $\begin{array}{c}\text { JURNAL } \\
\text { KOLABORASI RESOLUSI KONFLIK }\end{array}$ & VOLUME 1 & NOMOR 1 & HALAMAN 1-70 & $\begin{array}{c}\text { ISSN 2655-8823 }(p) \\
\text { ISSN - }(e)\end{array}$ \\
\hline
\end{tabular}

Dinas Pertanian dan Kehutanan Kabupaten Bogor dengan asumsi tidak menambah perbedaan kepentingan antar pihak-pihak yang berkonflik.

5. Dilakukan pengawasan pemerintahan desa, pemberian pengetahuan kepada masyarakat dalam mengelola konflik yang ada melalui pendampingan, serta peran serta yang lebih nyata dari Pemda Kabupaten Bogor atau dinas-dinas terkait untuk membantu menyelesakan konflik yang terjadi dan membantu meningkatkan kesejahteraan masyarakat.

6. Perusahaan hendaknya lebih berhati-hati dalam menanggapi tuntutan masyarakat, agar tidak memicu konflik yang kembali laten tersebut. Kekuatan sosial yang dimiliki mampu mendorong mobilisasi massa hingga tindakantindakan radikal atau recliming.

Selain itu, dilihat dari kacamata pekerja sosial sudah seharusnya pekerja sosial menjadi lebih peka dan tanggap dalam menyikapi isu-isu konflik yang ada di masyarakat. Karena pada hakikatnya tugas dari seorang pekerja sosial di bidang penanganan konflik adalah dapat sebagai mediator serta advocator bagi masyarakat kepada pihak konflik lainnya yang lebih berkuasa agar didengar aspirasinya dan konflik dapat terselesaikan dengan segera tanpa menimbulkan konflik yang berkepanjangan.

\section{DAFTAR PUSTAKA}

Astawa, Ktut Diara. 2015. Strategi Penyelesaian Konflik Tanah Perkebunan. Jurnal Pendidikan Pancasila dan Kewarganegaraan, Th. 28, Nomor 1

Fisher, S, D. I. Abdi, J. Ludin, R. Smith, dan S. Williams. 2001. Mengelola Konflik: Keterampilan dan Strategi untuk Bertindak. Kartikasari, S. N, M. D. Lapilatu, R. Maharani dan D. N. Rini
[Penterjemah]. The British Council. Jakarta.

Hidayati, Nur. 2003. Gerakan Petani Antara Radikalisme dan Kompromi. Kompas, 28 September 2003. Hlm. 30.

Ibrahim, Jabal Tarik. 2002. Sosiologi Pedesaan. UMM Pres. Malang.

Ilham, Mohammad. 2006. Analisa Konflik Pengelolaan Sumber Daya Alam Masyarakat Desa Sekitar Hutan (Studi Kasus Masyarakat Desa Curugbitung, Kecamatan Nanggung, Kabupaten Bogor, Propinsi Jawa Barat). Skripsi

Mitchell, Bruce, B. Setiawan, Dwita H. Rahmi. 2000. Pengelolaan Sumberdaya dan Lingkungan. Gadjah Mada University Press. Yogyakarta.

Tanahkita.id: Penolakan Masyarakat Atas Perpanjangan HGU PT. Hevea Indonesia. Diakses pada 15 Desember 2018 pukul: $\quad 12.30 \quad$ WIB http://tanahkita.id/v2/data/konflik/detil/ Wm1Scg

Kegiatan di Nanggung. Diakses pada 15 Desember 2018 pukul: 13.03 WIB https://perempuanberjuangwordpress.c om/2015/04/13/kegiatan-di-nanggung/

Teori Konflik Dan Konflik Agraria. Diakses Pada 15 Desember 2018 WIB Pukul: $\quad 13.48 \quad$ WIB http://uniridha.blogspot.com/2013/05/t eori-konflik-dan-konflik-agraria.html

Huma Id: 500 KK Petani Nanggung Terampas Haknya. Diakses pada 16 Desember 2018 pukul: 10.02 WIB https://huma.or.id/home/en/publikasi/k abar-dari-lapangan/500-kk-petaninanggung-terampas-haknya.html

Huma Id: Petani Bogor Demo TolakPerpanjangan HGU. Diakses pada 16 Desember 2018 pukul: 10.34 WIB https://huma.or.id/home/en/publikasi/k abar-dari-lapangan/petani-bogor-demotolak-perpanjangan-hgu.html. 